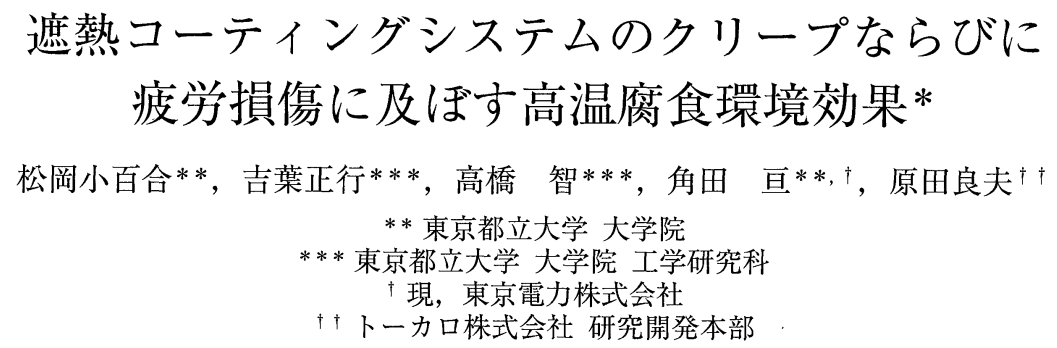

\title{
Effect of Hot Corrosive Environment on Creep and Fatigue Failure of Thermal Barrier Coating System*
}

\author{
Sayuri Matsuoka**, Masayuki Yoshiba***, Satoru Takahashi***, \\ Wataru Kakuta**, ${ }^{\dagger}$ and Yoshio Harada ${ }^{\dagger \dagger}$ \\ * * Graduate Student, Tokyo Metropolitan University \\ *** Department of Mechanical Engineering, Graduate School of Engineering, Tokyo Metropolitan University \\ $\dagger$ The Tokyo Electric Power Company, Incorporated \\ ${ }^{\dagger} \dagger$ Thermal Spraying Technology R\& D Laboratory, Tocalo Co., Ltd.
}

\begin{abstract}
Thermal barrier coating (TBC) systems, which have been inevitably introduced to the critical hot-section components such as blades and vanes of the advanced gas turbines, one required to assure the improved durability and reliability under the complicated modes of thermal-mechanical-chemical loadings. In the present paper, the stress rupture property evaluation and failure analysis were conducted for TBC system with the $\mathrm{Y}_{2} \mathrm{O}_{3}$ partially-stabilized $\mathrm{ZrO}_{2}$ top-coat in air and two kinds of the corrosive environments. Static creep loading was found to bring about the typical creep rupture behavior for TBC system similar to the no-coated Mar-M247 alloy in air regardless of aggressive environment. On the contrary, it was revealed that dynamic fatigue and creep-fatigue loadings tend to bring about a significant rupture life reduction of TBC system both in air and in corrosive environments, because the penetration crack pre-existing in the top-coat tends to provide a nucleation site for the fatigue crack in air, and the corrosion-fatigue crack in hot corrosive environment. In molten salt environment, furthermore, characteristic manner of crack propagation behavior was observed to occur such as crack branching and crack tip blunting, which should be rather effective for suppressing the crack propagation. Effect of the corrosive environments on such the crack behavior was discussed mainly from the viewpoint of dynamic fatigue crack propagation.
\end{abstract}

Key words : thermal barrier coating (TBC) system, Ni-base superalloy, $\mathrm{Y}_{2} \mathrm{O}_{3}$ partially-stabilized $\mathrm{ZrO}_{2}(\mathrm{YSZ})$, creep, fatigue, hot corrosion, failure analysis

\section{1. 緒言}

地球環境保全やエネルギー資源保存などの観点から， 発電用ガスタービンの高温高効率化が推進されており, 効率向上にとって不可欠のタービン入口燃焼ガス温度の 上昇により $1500^{\circ} \mathrm{C}$ 級の先進型ガスタービンが実用化され ている ${ }^{1)}$ ままた, 発電用ガスタービンでは燃料の多様化 に応じて，動静翼部などの高温部材では熱的-機械的一化 学的負荷による損傷が問題となる場合が多く, 特にこれ ら多様な負荷が重畳した厳しい作動条件下での優れた耐 久性と信頼性が要求される。このように複合化された過 酷環境において高温部材の強度特性と耐環境性を保証す るうえで，高強度超合金単独では限界があり，それゆえ 被曝温度低減が可能な遮熱コーティング（Thermal Barrier Coatings : TBCs) を中心とした耐熱コーティングシス テムの合理的設計と，実用作動条件下での信頼性保証の 確立が不可欠の状況にある.

* 第 51 回材料と環境討論会 (名古屋, 2004 年) にて一部発表

**,*** T 192-0397 八王子市南大沢 1-1 (1-1, Minami-Osawa, Hachioji, Tokyo, 192-0397 Japan)

$\dagger \dagger$ 于 674-0093 明石市二見町南二見 14-3 (14-3, Minami-Futami, Futami-Cho, Akashi, 674-0093 Japan)
このような背景から，TBC システムに関する研究は現 在まで精力的に展開され，ガスタービン動静翼部などへ の実用化も相当程度進んでいる1 ${ }^{1-6)}$. しかし, 実機運用 に扔いて問題となる熱的一機械的一化学的負荷の同時作用 条件下での複合型損傷挙動は極めて複雑なため, 現在で も不明な点が多く，それゆえ実機腐食環境を考慮した負 荷条件下に抢ける TBC システムの損傷劣化挙動の体系 的究明が急務と考えられる。

本研究では, 溶射方法で作製した $\mathrm{Y}_{2} \mathrm{O}_{3}$ 部分安定化 $\mathrm{ZrO}_{2}(\mathrm{YSZ})$ 系 $\mathrm{TBC}$ システムを対象として, 高温大気中, および実機環境を模擬した 2 種類の高温腐食環境中にお いて静的ならびに動的負荷条件下での破断特性評価と損 傷解析を行い, 多様な負荷条件下での損傷劣化挙動に及 ぼす高温腐食環境の影響について検討した.

\section{2. 供試材および実験方法}

基材合金として，普通鋳造による多結晶 $\mathrm{Ni}$ 基超合金 Mar-M247を用いた，その化学組成を Table 1 に示す. Mar-M247 合金素材に対して $1080^{\circ} \mathrm{C} \times 4 \mathrm{~h} \rightarrow$ 急冷 (Rapid Air Cooling : RAC) $+870^{\circ} \mathrm{C} \times 20 \mathrm{~h} \rightarrow$ 空冷 (Air Cooling : AC）による標準熱処理を施した後，平行部寸法 $\phi 6 \times 8$ $\mathrm{mm}$ の平滑丸棒試験片に機械加工し, 平行部表面を\# 
Table 1 Chemical composition of substrate superalloy Mar-M247 (mass\%).

\begin{tabular}{cccccccccc|cc}
\hline $\mathrm{C}$ & $\mathrm{Si}$ & $\mathrm{Mn}$ & $\mathrm{P}$ & $\mathrm{S}$ & $\mathrm{Cr}$ & $\mathrm{Co}$ & $\mathrm{Al}$ & $\mathrm{W}$ & $\mathrm{Ta}$ & \multicolumn{2}{c}{ Others } \\
\hline 0.14 & 0.05 & $<0.01$ & 0.002 & 0.001 & 8.33 & 10.05 & 0.7 & 0.86 & 3.05 & $\mathrm{Nb} 0.03$ & $\mathrm{Ti} 0.01 \mathrm{Cu}<0.01 \mathrm{Zr} 0.04$ \\
\hline
\end{tabular}

Table 2 Coating processing and reheat treatment for Mar-M247 (MB) and TBC system (MZV).

\begin{tabular}{|c|c|c|c|c|c|}
\hline $\begin{array}{l}\text { Process } \\
\text { Code }\end{array}$ & $\begin{array}{l}\text { Heat } \\
\text { Treatment }{ }^{* 1}\end{array}$ & $\begin{array}{l}\text { Grit } \\
\text { Blast }\end{array}$ & $\begin{array}{l}\text { Metallic Bond-Coat } \\
\text { (Thickness: } 100 \mu \mathrm{m})\end{array}$ & $\begin{array}{l}\text { Ceramic Top-Coat } \\
\text { (Thickness: } 200 \mu \mathrm{m})\end{array}$ & $\begin{array}{l}\text { Reheat } \\
\text { Treatment*1 }\end{array}$ \\
\hline MB & 0 & - & - & - & - \\
\hline MZV & 0 & 0 & VPS / CONICIAIY & APS / 6YSZ & $\mathrm{O} * 2$ \\
\hline
\end{tabular}

*1: $1080^{\circ} \mathrm{C} \times 4 \mathrm{~h} \rightarrow \mathrm{RAC}+870^{\circ} \mathrm{C} \times 20 \mathrm{~h} \rightarrow \mathrm{AC}$ ， * 2 : Solution Treatment in Ar Atmosphere

500 まで軸方向にエメリー研磨し, その後アセトン中で の超音波洗浄により完全に脱脂した. さらに, Table 2 に 示す一連のコーティングプロセスにより， $\mathrm{Al}_{2} \mathrm{O}_{3}$ グリッ トブラスト処理, Co-32Ni-21Cr-8Al-0.4Y(mass\%) 合金 粉末の減圧プラズマ溶射 (Vacuum Plasma Spraying : VPS) によるボンドコート (Bond-Coat : BC) 被覆, $\mathrm{ZrO}_{2}$ 6 mass\% $\mathrm{Y}_{2} \mathrm{O}_{3}$ (6YSZ) 粉末の大気プラズマ溶射 (Atmospheric Plasma Spraying : APS) によるトップコート (TopCoat : TC) 被覆, 後熱処理を順次施した.このようにし て作製した TBC システム試験片 $(\mathrm{MZV})$ の典型的断面組 織を Fig. 1 に示すが，TC 中には主に後熱処理過程で導 入されたと思われる貫通き裂が認められる. 本論文では, このようにあらかじめ存在する貫通き裂を「先在き裂」 と呼称する.また比較材として, 標準熱処理を施した Mar-M247 無被覆材の試験片（MB）も用いた。

高温強度試験は電気油厈サーボ式瘦労試験機を使用 し, Table 3 に示した忍力波形によるクリープ (C), 三角 波疲労 $(\mathrm{F})$, 台形波によるクリープ-疲労 $(\mathrm{CF})$ の各負荷 条件での軸荷重制御試験を $850^{\circ} \mathrm{C}$ と $950^{\circ} \mathrm{C} て ゙$ 実施した. なお，負荷応力は溶射前の基材合金の断面寸法に基づい て決定している．試験環境条件は 3 種類設定した。すな わち, 大気中 (Air) を基準環境とし, ガスタービン燃焼 ガス雲囲気をシミュレーションした $\mathrm{N}_{2}-5 \% \mathrm{O}_{2}-10 \% \mathrm{CO}_{2}$ $2 \% \mathrm{SO}_{2}(\mathrm{vol} \%)$ 組成のガス雾囲気中 (Gas), さらにガス タービン動静翼表面への溶融塩の付着堆積に起因したホ ットコロージョン環境を想定して $90 \% \mathrm{Na}_{2} \mathrm{SO}_{4}-10 \% \mathrm{NaCl}$ 混合塩を $10 \mathrm{mg} / \mathrm{cm}^{2}$ の割合で試験片平行部表面に塗布

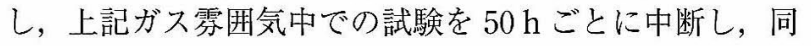

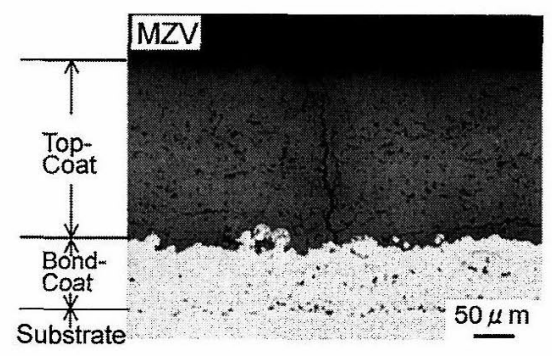

Fig. 1 Typical cross-sectional microstructure for TBC system (MZV).

量の混合塩を繰り返し塗布する溶融塩腐食巏境中 $(G-10$ S）の 3 条件で強度試験を実施した。 ただし， $950^{\circ} \mathrm{C}$ 程度 以上になると溶融塩の付着堆積に起因する溶融塩腐食が かえって軽減されることが既に分かっているので3， $950^{\circ} \mathrm{C}$ に㧍ける溶融塩腐食環境中試験は実施していない. 試験終了後の試験片に対しては, 軸方向断面の光学顕微 鏡観察や EPMA 分析, 破面の SEM 観察などに基づく損 傷解析を綿密に行ったが, 特に EPMA 分析用試料の切 断・研磨などの準備はすべて乾式で行い, 腐食性物質の 保存に十分配慮した。

\section{3. 実 験 結 果}

\section{1 高温大気中における破断強度特性}

大気中における各負荷条件下での無被覆材 (MB) なら びに TBC システム (MZV) の応力破断特性を Fig. 2 に示 す。なお, 図中の線は, それぞれの温度一負荷条件にお

Table 3 Mechanical testing conditions.

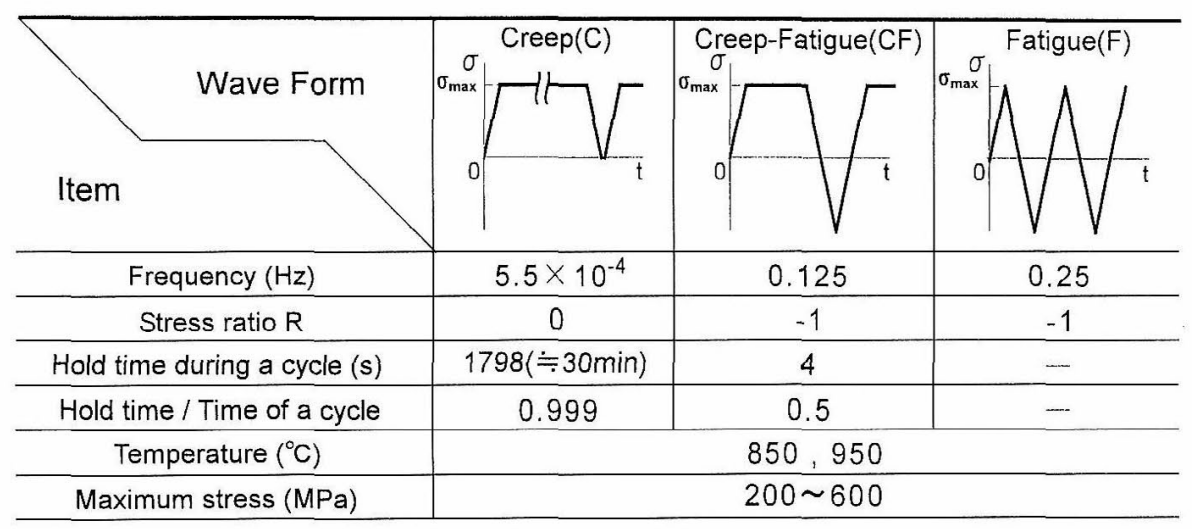




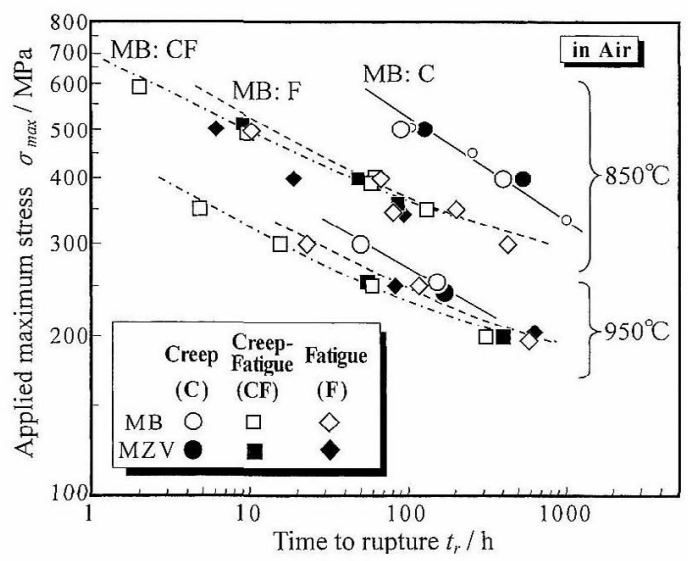

Fig. 2 Stress rupture properties at 850 and $950^{\circ} \mathrm{C}$ in air for MarM247 (MB) and TBC system (MZV). Symbol of small open circle denotes reference creep data for Mar-M247 ${ }^{7)}$.

ける無被覆材の応力破断特性傾向を表す。無被覆材の破 断寿命は, 静的クリープ (C) 条件下に比べて, 疲労 $(\mathrm{F})$ やクリープー疲労 $(\mathrm{CF})$ 条件下で著しく低下した。この ような寿命低下傾向は $850^{\circ} \mathrm{C}$ の高応力域で，特にクリー プ-疲労条件下で顕著である。しかし， $850^{\circ} \mathrm{C} の 400 \mathrm{MPa}$ 以下の低応力域では疲労とクリープ-疲労の破断寿命は ほぼ同程度となり，ともに静的クリープ破断寿命に漸近 する傾向がみられる、さらに，950 $\mathrm{C}$ の低応力域になる と, タリープと疲労における寿命の大小関係がむしろ逆 転する傾向がみられる。また疲労ならびにクリープー疲 労条件下での応力破断特性は, 温度によらずほぼ同様の 傾向を示し, 応力低下に伴って直線的外挿值よりも長寿 命化し, 疲労限度の存在をうかがわせるような傾向を示 している.しかし，このような動的負荷条件下における 破断特性を最大忍力と破断繰返し数の関係で整理すると Fig. 3 のようになり, クリープー疲労では純粋痩労に比べ て相当少ない繰返し数で破断することがわかる．したが って，クリープ-疲労における損傷が疲労主導型であっ てもクリープ損傷の影響も無視できず，クリープ損傷之 疲労損傷の重畳効果によって損傷が促進されたと考える べきであろう ${ }^{8)}$. 特に $950^{\circ} \mathrm{C}$ の低応力側では破断繰返し数 の格差が拡大していることから,クリープ-疲労 における破断寿命は疲労損傷よりも相対的にクリ ープ損傷主導により決定される可能性が増大する ものと考えられる.

一方， TBC システムの破断寿命は，静的クリー プ条件下では温度によらず，無被覆材と同程度以 上であり，応力の低下に伴いほほ淔線的に増大し た。これに対して $850^{\circ} \mathrm{C}$ 疲労条件下では, 無被 覆材に比べて破断寿命が著しく低下し，特に 400 MPa 以上の高応力レベルで最も顕著であった。し かし, クリープー疲労条件下では無被覆材と同程 度の破断寿命であり，それゆえ $850^{\circ} \mathrm{C}$ 高応力レベ ルにおける TBC 損傷に対する動的繰返し応力の 有害性が示唆される。このように, TBC システム では無被覆材の場合に比べて動的負荷, とりわけ 疲労による寿命低下が最も媣刻化することが明ら

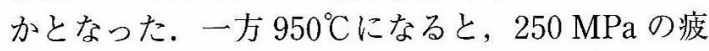
労条件下では無被覆材よりも TBC 材の破断寿命

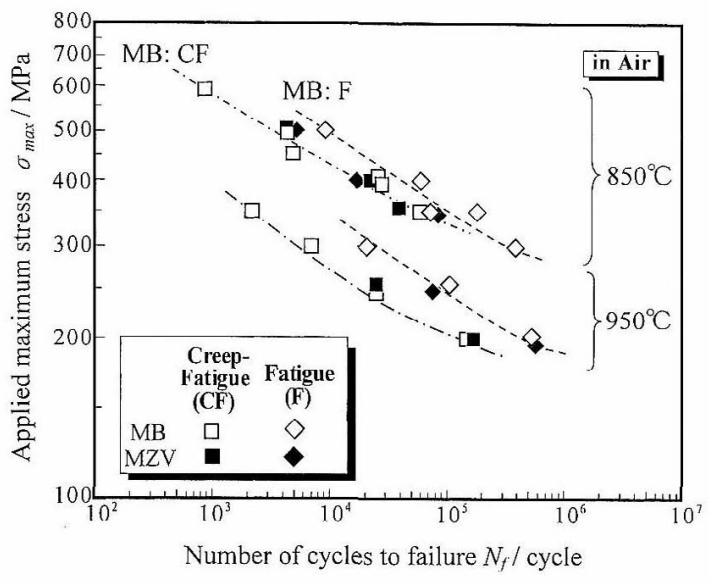

Fig. 3 S-N curves of Mar-M247 (MB) and TBC system (MZV) at 850 and $950^{\circ} \mathrm{C}$ in air.

が若干低下しているが，200 MPaでは無被覆材とほぼ同 程度になり，全般的に破断寿命の低下傾向が $850^{\circ} \mathrm{C}$ の場

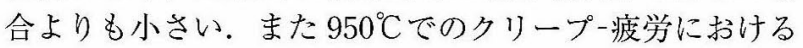
TBC システムの破断寿命は無被覆材とほぼ同程度で, と もに疲労 (F) 寿命よりも短くなっており, それゆえ前述 のとおり動的疲労と静的クリープ双方の損傷因子が問題 となる。

\section{2 高温大気中における損傷挙動}

静的クリープ (C) 条件下で破断した無被覆材 (MB) と TBC システム $(M Z V)$ の典型的な縱断面光学顕微鏡組織 を Fig. 4 に示す. 無被覆材では表而き裂が, 一方 TBC シ ステムでは TC 貫通き裂の開口部とその直下の $\mathrm{BC}$ 部に おいて集中的損傷形態が認められるものの, いずれの場 合も基本的には基材合金内部の結晶粒界から核発生した き裂が, 粒界や一部デンドライト境界などを選択的に進 展し, 成長・合体を繰り返して最終破断に至る典型的ク リープ損傷の様相を呈していた。

次に, 疲労 (F) 条件下で破断した無被覆材の縦断面反 射電子像を Fig. 5 に示す。無被覆材において認められる 表面き裂は，W や Ta を主体とする MC 型炭化物を核と
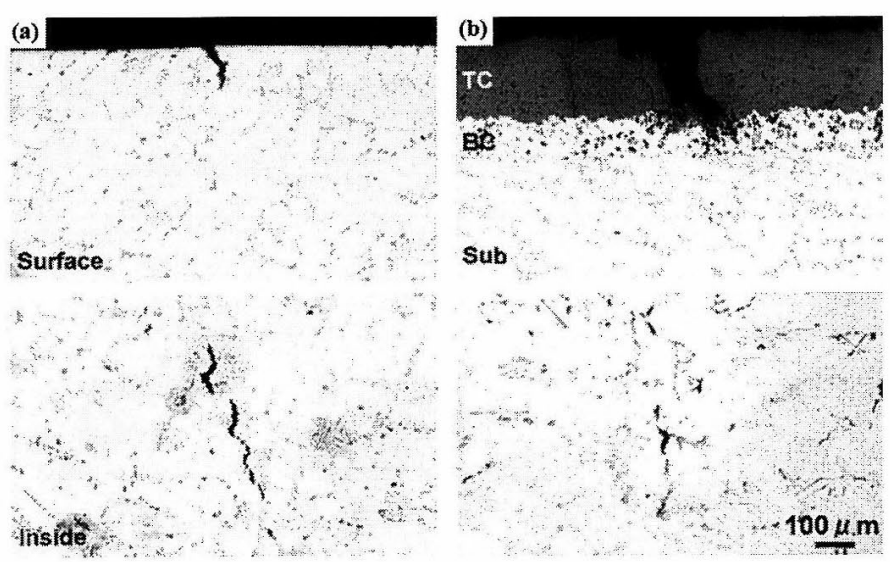

Fig. 4 Optical micrographs at the longitudinal section of specimen surface zone creep-ruptured at $850^{\circ} \mathrm{C}$ in air under the maximum stress $500 \mathrm{MPa}$; (a) Mar-M247 (MB, $\left.t_{\mathrm{r}}=90 \mathrm{~h}\right)$ and (b) TBC system $\left(M Z V, t_{\mathrm{r}}=127 \mathrm{~h}\right)$. Stress axis is horizontal. 


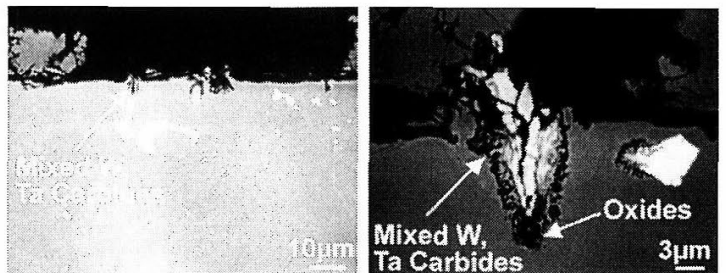

Fig. 5 Typical microstructures by back scattered electron (BSE) image at the longitudinal section of Mar-M247 (MB) specimen surface zone fatigue-failed at $850^{\circ} \mathrm{C}$ in air under the maximum stress $500 \mathrm{MPa}\left(t_{\mathrm{r}}=10 \mathrm{~h}\right)$. Stress axis is horizontal.

して生長する傾向が強く，また残存する長大な疲労き裂 は全く確認できなかった。したがって，このような観察 事実から，試験片表面に露出した炭化物あるいはこれの 酸化された領域を起点として早期に発生した疲労き裂の 急速な伝播により破断が促進されたため，静的クリープ 条件下よりも著しい寿命低下を生じたものと考えられ る。

これに対してTBC システムでは，Fig. 6 に示す縦断面 光学顕微鏡組織から明らかなように，TC中にあらかじ め存在する貫通き裂先端から疲労き裂が成長して，BC さらには基材合金内部へと進展している様子が観察され た.また Fig. 6(b) にホしたように，低応力長寿命側に なると基材合金内部に進展したき裂部分が著しく酸化さ れる傾向が強くなり，それゆえ低応力域では力学的痩労 損傷が軽減される一方で，このような酸化現象がき裂進 展を促進させる要因となる可能吽が示唆される。

\section{3 高温腐食環境中における破断強度特性}

2 種類の腐食環境に抢ける無被覆材 $(\mathrm{MB})$ と TBC シス テム (MZV) の応力破断特性を Fig. 7 に示す.なお, 図 中の 3 種類の線は, それそれれ温度と負荷条件における 無被覆材の大気中での応力破断特性傾向 (Fig. 2) を表す. 無被覆材では温度や負荷応力様式によらず，腐食環境に 対する感受性が極めて高く，大気中に比べて破断寿命が 著しく低下した，特に破断寿命低下は溶融塩腐食環境中 （G-10S）で最も深刻であり，ガス雾囲気 (Gas) でも相当 程度認められた。ガス雲囲気に扔いては，950よりも $850^{\circ} \mathrm{C}$ で寿命低下が顕著であった。さらに，この腐食誘 起破断寿命低下傾向は静的クリープ条件下に比べて疲労 やクリープ-疲労などの動的負荷条件下で一層促進され る可能性が高い.

一方 TBC システムの応力破断特性は, 負荷応力様式 や温度，環境条件の組合せに依存して著しい相違がみら れた。すなわち静的クリープ条件下では，TBC システム の腐食による寿命低下は無被覆材とは対照的にほとんど みられず，コーティング層による耐食性改善效果が有効 に発揮されていることが確認された。これに対して動的 負荷の波労ならびにクリープ-疲労負荷条件下では，い ずれの腐食環境においても著しい破断寿命低下が認めら れ，とりわけガス雲囲気巾で短寿命となる傾问にあった。 ただし，ガス雲囲気中に比べて溶融塩腐食環境中では， 破断寿命の応力依存性が低下する傾向にあることから， さらに低応力長寿命域になると破断寿命の大小関係に逆 転が生じる可能性もある。また，破断寿命の低下は
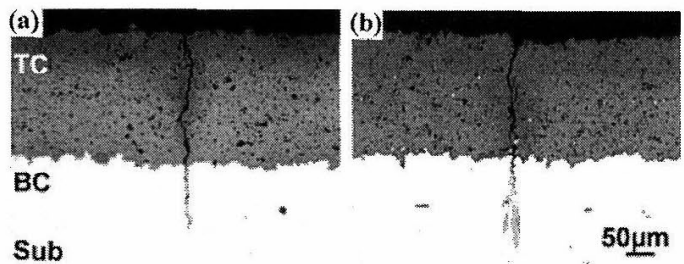

Fig. 6 Optical micrographs at the longitudinal section of MZV specimen surface zone fatigue-failed at $850^{\circ} \mathrm{C}$ in air; (a) maximum stress $500 \mathrm{MPa}\left(t_{\mathrm{r}}=6.1 \mathrm{~h}\right)$ and $(\mathrm{b})$ maximum stress $350 \mathrm{MPa}\left(t_{\mathrm{r}}=94 \mathrm{~h}\right)$. Stress axis is horizontal.

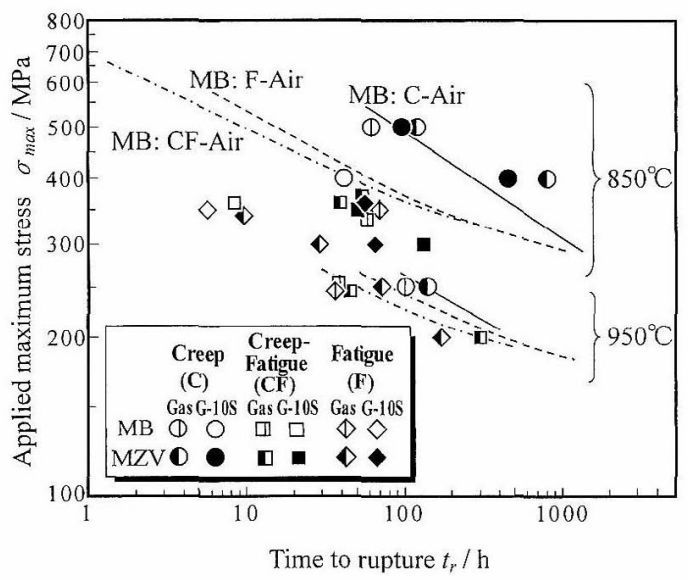

Fig. 7 Stress rupture properties at 850 and $950^{\circ} \mathrm{C}$ in gaseous atmosphere (Gas) and molten salt environment (G-10S) for Mar-M247 (MB) and TBC system (MZV).

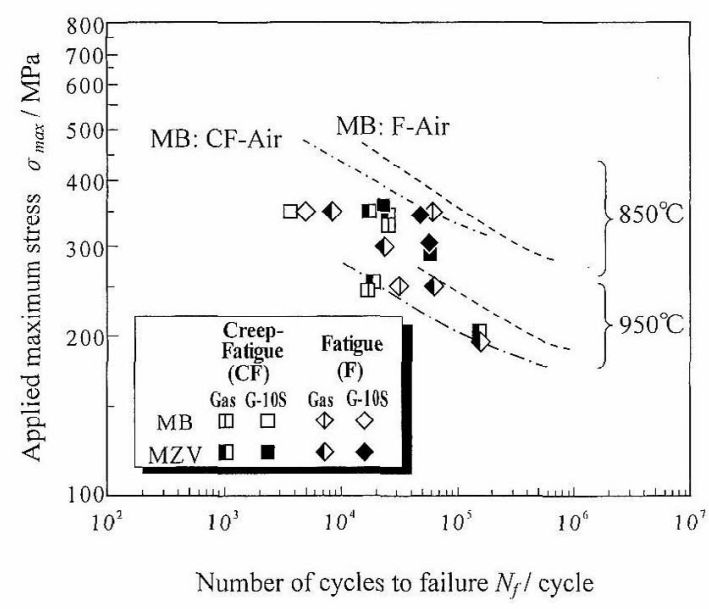

Fig. 8 S-N curves of Mar-M247 (MB) and TBC system (MZV) at 850 and $950^{\circ} \mathrm{C}$ in gaseous atmosphere (Gas) and molten salt environment (G-10S).

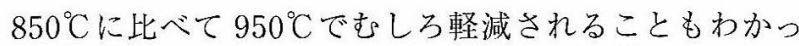
た. 最大応力と破断繰这し数の関係を Fig. 8 に示すが, 両試験温度において応力レベルが低下するとクリープー 疲学と純粋疲労とにかかわらず同程度のサイクル数で $\mathrm{TBC}$ システムが破断していることから，腐食環境中での 損傷促進に対しては動的負荷が主要な役割を果たしてい る可能性が示唆される.

腐食環境の効果が最も顕在化した $8500^{\circ} \mathrm{Cにおいて，}$ 各負荷様式による代表的応力レベルにおける大気中破 


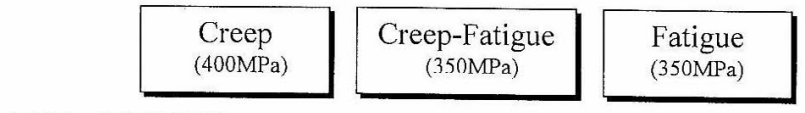

(a) Mar-M247 (MB)

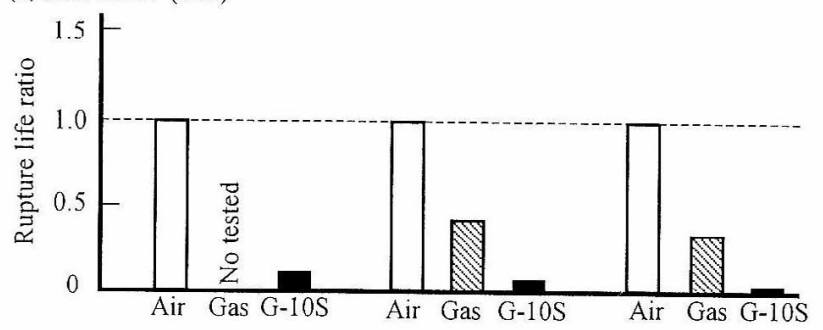

(b) TBC system (MZV)

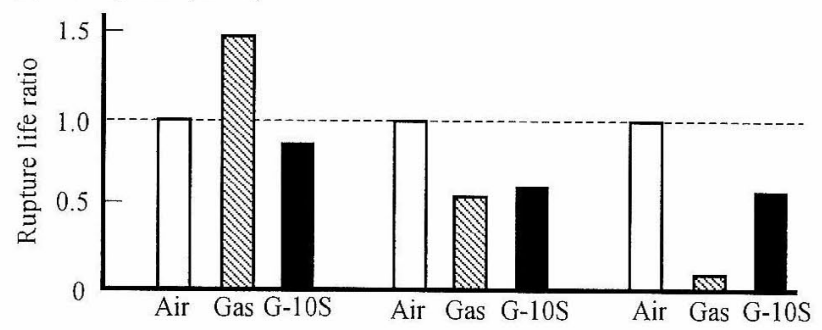

Fig. 9 Influence of aggressive environments on rupture life at $850^{\circ} \mathrm{C}$; (a) Mar-M247 (MB) and (b) TBC system (MZV). Rupture life ratio is $t_{\mathrm{r}}{ }^{\text {corr }} / t_{\mathrm{r}}^{\text {air }}$. Air : in air, Gas : in gaseous atmosphere, G-10S : in molten salt environment

断寿命を基準にした場合の腐食環境での破断寿命比

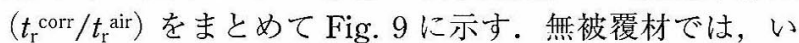
ずれの負荷条件においても腐食環境中での破断寿命低下 が大きく, とりわけ溶融塩腐食環境中で最も媣刻化する. これに対して TBC システムでは，応力負荷様式に依存 して著しい相違がみられた。まず静的負荷条件下では， 大気中に比べてガス䨌囲気中の方がむしろ長寿命化し， また溶融塭腐食環境中でも寿命低下は無被覆材に比べて 格段に抑制されている。これに対して動的負荷条件下で は，溶融塭腐食環境中よりもむしろガス雲囲気中での寿 命低下が著しく，特に疲労条件下で最も深刻である。こ のように，ガス雲囲気中の疲学条件下では寿命低下が顕 著であるが，これを例外とすれば腐食環境による破断寿 命の低下率は全般に無被覆材に比べて小さく抑えられて いる.

\section{4 高温腐食環境中における損傷挙動}

各負荷様式に打ける損傷形態の代表例として, $850^{\circ} \mathrm{C}$ ガス雾囲気中でクリープ (C) 破断した無被覆材 (MB) お よび TBC システム $(M Z V)$ の典型的縦断面光学顕微鏡組 織を Fig. 10 に示す。無被覆材では表面き裂周辺部に，一 方 $\mathrm{TBC}$ システムでは TC 貫通き裂直下の $\mathrm{BC}$ 層において 局所的に腐食が生じていたが，これらを起点とした優先 的なき裂成長は認められなかった。また，溶融塩腐食環 境中でも基本的には同様な損傷形態であった。すなわち， 本研究における温度一応力レベルでは大気中と同様，両 材とも合金内部の結晶粒界から発生したクリープき裂が 合体・伝播して最終破断に至る典型的クリープ損傷の様 式を示している。このような損傷挙動は，基材合金は異 なるものの， $\mathrm{Ni}$ 基鍛造合金を基材合金とする他の $\mathrm{TBC}$ システムに対する著者らの結果と一致している要。した
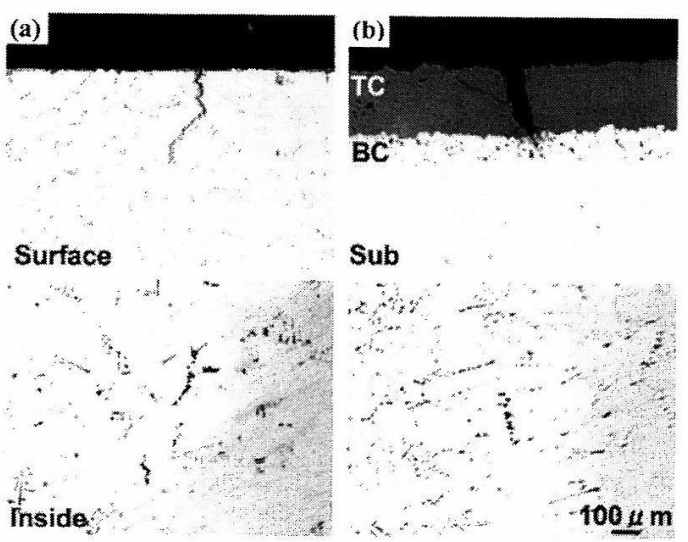

Fig. 10 Optical micrographs at the longitudinal section of specimen surface zone creep-ruptured at $850^{\circ} \mathrm{C}$ in gaseous atmosphere; (a) Mar-M247 at maximum stress $500 \mathrm{MPa}$ $\left(\mathrm{MB}, t_{\mathrm{r}}=61 \mathrm{~h}\right)$ and $(\mathrm{b}) \mathrm{TBC}$ system at maximum stress $500 \mathrm{MPa}\left(\mathrm{MZV}, t_{\mathrm{r}}=117 \mathrm{~h}\right)$. Stress axis is horizontal.

がって，静的負荷条件下では腐食環境による損傷挙動へ の影響は軽微と考えてよい.

一方，動的負荷条件下での $\mathrm{TBC}$ システムの損傷挙動 は，環境条件に依存して著しい相違がみられた。2 種類 の腐食環境中において動的負荷条件下で損傷を受けた TBC システム試験片の典型的縦断面 EPMA 分析結果を Fig. 11 に示す.まず $850^{\circ} \mathrm{C}$ のガス雲囲気中では，機械的 負荷主導型損傷を示唆する直線的なき裂形態を呈してい るが，き裂先端部では $\mathrm{O}$ と S の濃化が認められた。この ことから，TC 中に先在，あるいは動的試験の初期段階 で容易に生長する貫通き裂が腐食性成分の短絡経路とな $り$ ，き裂先端部における硫化-酸化反応 ${ }^{10)}$ に基づく腐食 作用がき裂進展を促進する結果，大気中に比べて著しい 早期破断を招来したものと考えられる． $950^{\circ} \mathrm{C}$ ガス雲囲 気中での損傷挙動は，基本的に $850^{\circ} \mathrm{C}$ の場合と同様であ るが，破断寿命の著しい低下は $850^{\circ} \mathrm{C} に$ 比べてむしろ軽 減される傾向にある。

これに対して $850^{\circ} \mathrm{C}$ の溶融塩腐食環境中では，損傷挙 動は基本的にガス雲囲気中の場合と同様であったが，溶 融塩の強い腐食作用により，TC 貫通き裂直下の $\mathrm{BC}$ 部 位で局所的に著しい腐食損散が認められた。このため, き裂先端部での腐食による疲労き裂促進が問題となる が，その一方では基材合金内部で屈曲したき裂進展経路 をたどると同時に，腐食生成物によるき裂先端の鈍化 （blunting）やき裂の分岐（branching）など溶融塩腐食環 境中特有のき裂進展形態が確認された。

\section{4. 考察}

\subsection{TBC システムの大気中損傷挙動に及ぼす負荷条 件の影響}

大気中における $\mathrm{TBC}$ システムの損傷解析の結果, 損 傷劣化挙動の温度による相違は大きくない反面, 応力負 荷条件によって著しい相違が認められた. すなわち静的 クリープ条件下での損傷挙動は，基材合金内部の粒界か らき裂が発生し，その後，粒界や一部デンドライト境界 などを選択的に進展し，成長・合体を繰り返して最終破 断に至る典型的クリープ損傷を生じる。このような損傷 

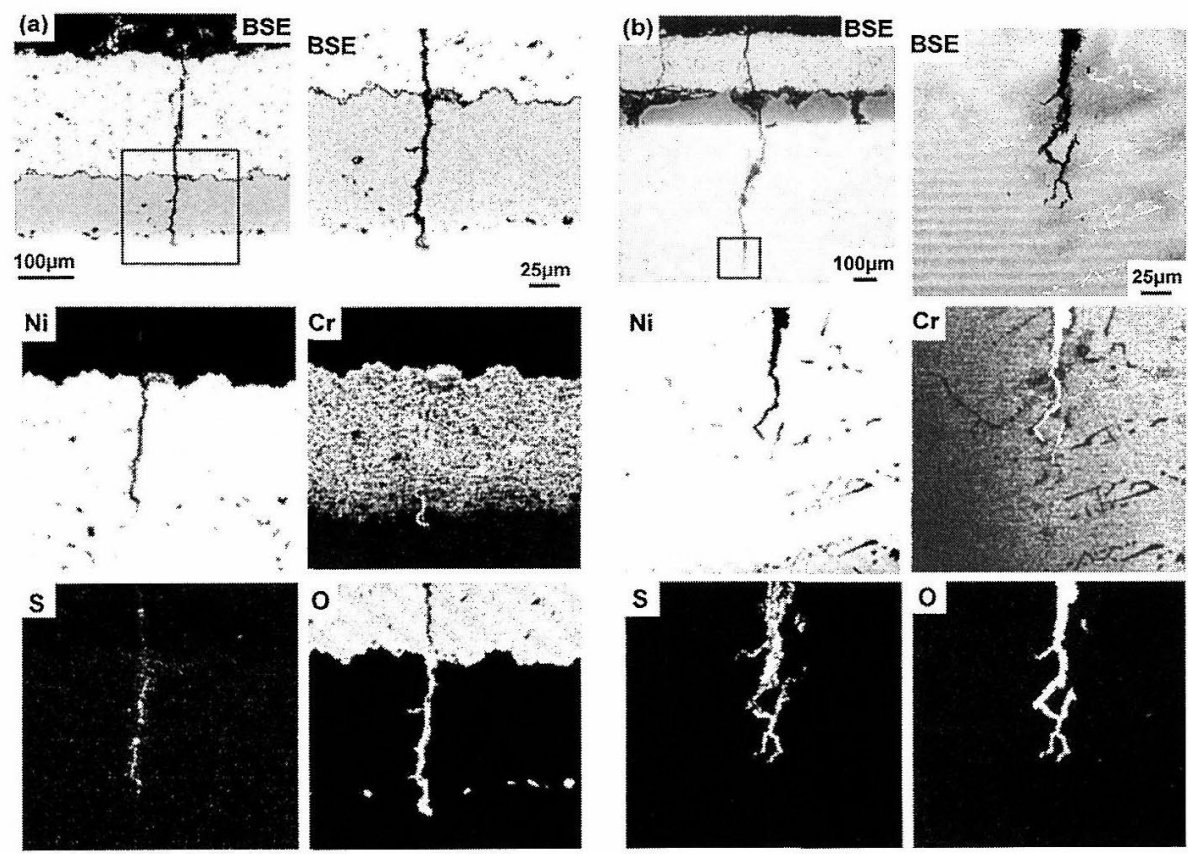

$\mathbf{N i}$

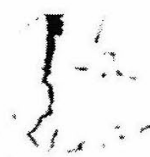

\section{.}
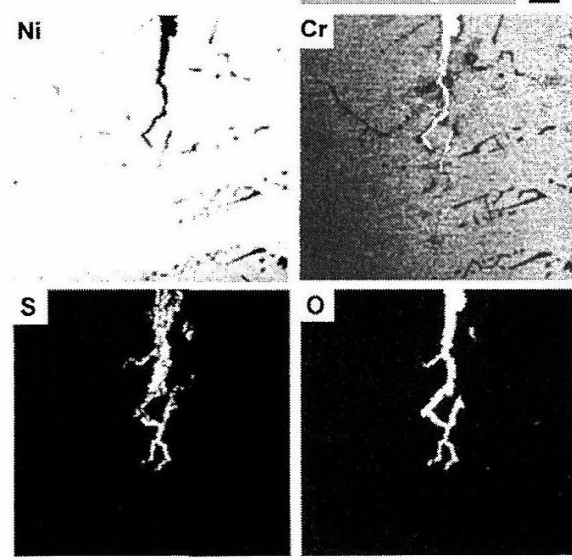

Fig. 11 BSE and characteristic X-ray images at the longitudinal section of TBC system specimen (MZV) ruptured at $850^{\circ} \mathrm{C}$ under the maximum stress $350 \mathrm{MPa}$; (a) in gaseous atmosphere under fatigue loading $\left(t_{\mathrm{r}}=9.5 \mathrm{~h}\right)$ and $(\mathrm{b})$ in molten salt environment under creep-fatigue loading $\left(t_{\mathrm{r}}=52 \mathrm{~h}\right)$. Stress axis is horizontal.
てすでに実証されている13). $950^{\circ} \mathrm{C}$ ガス需囲気中での損傷 挙動も基本的には $850^{\circ} \mathrm{C}$ の場 合と同様である。しかし機械 的負荷応力レベルが低下した ため，き裂進展に対する腐食 損傷の影響が相対的に強まる ものの, $\mathrm{BC}$ 層の優れた噮境 遮蔽機能によってき裂進展が 逑延される可能性が増大す る. それゆえ, $950^{\circ} \mathrm{C}$ ガス雲 囲気中では, 応力レベルの低 下とも相まって $850^{\circ} \mathrm{C} に$ 比べ て破断寿命低下率が軽減され たものと考えられる.

一方溶融塩腐食噮境中で は，破断寿命の低下率がガス 雲囲気中よりもむしろ軽減さ れた. そして溶融塩腐食環境 中では, ガス雲囲気中と同粎 にき裂先端部で局部腐食が確 認されており，これによるき 裂進展促進が問題となるが, その一方では腐食生成物によ
挙動は本質的に無被覆材と同様であり，TC 層内にあら かじめ存在する貫通き裂の悪影響は問題にならない.ク リープ負荷条件下では一般的に，两滑材よりむしろ切欠 き材において長寿命化する場合が多い。これは，切欠き 先端部が多軸応力状態となって塑性拘束作用を生じ, 切 欠き強化をもたらすためである11), 12)。したがって静的負 荷条件下では，本研究に扔いても TBC システムの TC 層 内にあらかじ存在する貫通き裂は, 破断特性に対して 少なくとも悪影響を及ぼさないと考えてよい。

これに対して動的負荷条件下での損傷挙動は，TC 中 の先在貫通き裂の先端から早期に発生した疲学き裂が成 長し， BC や基材合金内部へと進展して直接破断を引き 起こす。すなわち，TC 層が疲労き裂の発牛過程に直接 関与し，き裂発生時期が早期化するため, 動的負荷条件 下では無被覆材に比べて, TBC システムの破断寿命低下 が顕在化したものと考えられる。しかし，このような力 学的要因主導によるTC 貫通き裂部からの疲労き裂の早 期発生傾向も高温低応力側では相対的に軽減されるた め, $950^{\circ} \mathrm{C}$ の低応力域ではあまり深刻化しなくなったも のと考えられる.

\section{2 動的負荷条件下における TBC システムのき裂生 長挙動に及ぼす腐食環境効果}

腐食環境中における TBC システムの損傷劣化は動的 負荷条件下で顕在化し, 特に大気中に比べて著しい寿命

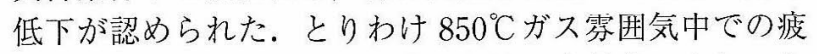
労条件下では，巨視的き裂進展経路が直線的であり，き 裂進展が力学的損傷主導型で起こった形跡を示してい る.ささらに, き裂先端部における硫化-酸化反応10)に基づ く腐食作用がき裂進展を助長して早期破断を招いたもの と考えられる. $\mathrm{SO}_{2}$ や $\mathrm{H}_{2} \mathrm{~S}$ 含有ガス雲囲気における $\mathrm{Ni}$ 基超合金の疲労き裂進展速度の増大は多くの研究におい
るき裂先端の鈍化やき裂の分岐という溶融塩腐食環境特 有のき裂形態もまた確認されている．破断試験片に対す る損傷解析に基づき, 腐食環境中における動的負荷条件 下でのき裂進展に影響を及ぼし得る諸要因をまとめる と, Table 4のように表すことができる. すなわち, 本研 究で考慮すべき影響因子として，（1）腐食作用（反応性 の強弱)，(2）き裂先端部の鈍化，（3）き裂の分岐の 3 つ が挙げられる。これらのうち, 腐食作用の最も強い溶融 塩腐食 $(\mathrm{G}-10 \mathrm{~S})$ 環境はき裂進展を促進する要因となる一 方，き裂の鈍化や分岐といったき裂形態の変化はともに き裂進展をかえって遅延させる効果がある14). 特にこれ ら (2), (3) の現象は, き裂先端部での有効応力拡大係数 範囲を減少させ, き裂進展を遅延させる要因となること がこれまでの研究からも指摘されている14)-16). またこれ 以外にも，き裂部における腐食生成物のくさび効果によ るき裂進展の遅延効果も考えられる17). したがって，こ れら腐食環境中特有のき裂進展に詨する噮境効果が重宣 した結果, ガス雲囲気中に比べて溶融塩腐食環境中では 破断寿命低下傾向がかえって軽減されたものと考えられ

Table 4 Effect of hot corrosive environment (Gas : in gaseous atmosphere, G-10S : in molten salt environment) on crack propagation behavior under dynamic loading conditions as compared with the case in air.

\begin{tabular}{c|c|c}
\hline \multirow{2}{*}{ Affecting Factor } & \multicolumn{2}{|c}{ Environment } \\
\cline { 2 - 3 } & Gas & G-10S \\
\hline Corrosive Reaction & $\uparrow$ & $\downarrow$ \\
\hline Crack Branching & - & $\downarrow$ \\
\hline Crack Tip Blunting & - & $\downarrow$ \\
\hline & : Crack propagation enhanced \\
$\downarrow:$ : Crack propagation restrained \\
$-:$ Not observed
\end{tabular}


る。このような疲労き裂生長挙動に対する腐食環境効果 は低応力長寿命側で顕在化するものと予想されるが，そ こでの TBC システムの有効性と腐食損傷主導型の損傷 劣化挙動に対しては,さらに低応力長寿命域での実験的 検証が必要である。

\section{5. 結}

\section{言}

$\mathrm{Ni}$ 基超合金 Mar-M247 を基材とする YSZ 系 TBC シス テムに対して大気中, ガス雲囲気中, $\mathrm{Na}_{2} \mathrm{SO}_{4}-\mathrm{NaCl}$ 系溶 融塩を含む溶融塩腐食環境中で静的クリープと動的な疲 労ならびにクリープ-疲労試験を $850^{\circ} \mathrm{C}$ と $950^{\circ} \mathrm{C}$ で行い, 損傷解析に基づいて破断特性に及ぼす腐食環境効果を検 討した，得られた結果を要約すると以下のようになる。

（1）大気中の静的クリープ条件下において，TBC シ ステムは基材合金内部で発生した粒界き裂が成長・合体 して最終破断に至る典型的クリープ損傷の様相を呈し, 無被覆材と本質的に同様の損傷挙動であった。これに対 して動的負荷条件下では，TC 中にあらかじめ存在する 貫通き裂が疲労き裂の起点となるため, 無被覆材に比べ て TBC システムの破断寿命が著しく低下した。

（2）静的クリープ条件下では，ガス雲囲気中および 溶融塩腐食環境中ともに, TBC システムは大気中と同様 の典型的クリープ損傷挙動を示し, 腐食損傷は全般的に 軽微であった。

（3） ガス䨌囲気中の動的負荷条件下では，TBC シス テムの TC 内に発達した貫通き裂が力学的損傷要因とな るとともに, 腐食性成分の容易侵入経路を提供する可能 性が高く，き裂先端部での硫化-酸化反応に基づく腐食 作用がき裂進展を促進するため, 大気中に比べて著しい 破断寿命低下を招く．ただし，応力レベルが低下すると 腐食損傷主導型のき裂進展傾向が強まるため, $\mathrm{BC}$ 層の 優れた環境遮蔽機能によって基材合金内部へのき裂進展 が遅延される可能性が増大する。このため, ガス䨌囲気 中での破断寿命低下傾向は $850^{\circ} \mathrm{C} よ り も 950^{\circ} \mathrm{C}$ の方が軽 減される。
（4）溶融塩腐食環境中では，溶融塩成分による腐食 作用のためにき裂進展が促進される一方，腐食反応生成 物によるき裂先端部の鈍化やき裂の分岐など腐食環境中 特有のき裂進展挙動が生じるため，これらの総合的な効 果によりガス雲囲気中よりもき裂進展がかえって遅延 し，破断寿命低下が軽減される可能性もある。

終わりに，本研究の遂行にあたり，信頼性の高いコー ティング試料の作製にご協力いただいたトーカロ(株) 溶 射技術開発研究所 谷 和美所長以下, スタッフの皆様, および卒研生として実験に協力された東京都立大学工学 部学生 山本 昂氏に謝意を表します.

\section{参 考 文 献}

1) Y. Yoshioka, H. Doi, J. Takeda, K. Namba, I. Okada, K. Take and T. Ito, J. Gas Turbine Soc. Jpn., 32-3, 130 (2004).

2) M. Yoshiba, J. Gas Turbine Soc. Jpn., 30-6, 483 (2002).

3) M. Yoshiba, J. Gas Turbine Soc. Jpn., 25-97, 57 (1997).

4) M. Yoshiba, J. Gas Turbine Soc. Jpn., 25-98, 80 (1997).

5) M. Yoshiba, J. Gas Turbine Soc. Jpn., 25-100, 18 (1998)

6) M. Yoshiba, J. Gas Turbine Soc. Jpn., 26-101, 63 (1998)

7) J. R. Davis, Heat-Resistant Materials, ASM, 243 (1997).

8) H. Sehitoglu and D. A. Boismier, J. Eng. Mat. and Tech. Trans. ASME, 80-112, 80 (1990).

9) M. Yoshiba, K. Wada and Y. Harada, J. Jpn. Inst. Met., 62 4, 333 (1998).

10) B. Pieraggi, Mater. Sci. and Eng., 88, 199 (1987).

11) R. Ohtani and T. Ito, J. Soc. Mater. Sci. Jpn., 20-214, 864 (1970).

12) M. Ohnami and K. Umeda, J. Soc. Mater. Sci. Jpn., 22-234, 278 (1972).

13) S. Floreen and R. H. Kane, Metall. Trans. A, 10, 1745 (1979).

14) M. Yoshiba, Prep. 20th Corrosion Seminar, JSCE, p.73 (1993).

15) W. Hoffelner, Metall. Trans. A, 13, 1245 (1982).

16）萩原芳彦，鈴木秀人，「よくわかる破壊力学」，p.91，才 一公社 (2000).

17）大谷隆一, 駒井謙治郎, 「環境 - 高温強度学, 総合材料 強度学講座 7$\rfloor,$ p.87, オーム社 (1984)

(Manuscript received November 30, 2004; in final form March 3, 2005)

遮熱コーティングシステム (Thermal Barrier Coating : TBC) は, 先進型ガスタービン動静翼部などのよ うなクリティカルな高温部材において必要不可欠であり, 熱的一機械的一化学的負荷が重畳した複合モード における優れた耐久性と信賴性保証が要求されている。本研究では, $\mathrm{Y}_{2} \mathrm{O}_{3}$ 部分安定化 $\mathrm{ZrO}_{2}$ をップコー 卜に用いた TBC システムに対し, 大気中と 2 種類の腐食環境中で応力破断特性評価と損傷解析を実施し た．静的クリープ負荷条件下では，腐食性環境にもかかわらず，TBC システムは大気中における無被覆 材の Mar-M247 合金と同様に典型的なクリープ損傷挙動を示すことが明らかになった。これに対して動 的な疲労ならびにクリープ-疲労負荷条件下では，大気中および高温腐食環境中いずれにおいても，TBC システムの著しい破断寿命低下を招く傾向にあった。これはトップコート中にあらかじめ存在する貫通き 裂が大気中における疲労き裂，ならびに腐食環境中に扔ける腐食一疲労き裂の核形成サイトを提供する傾 向にあるためである．さらに，高温溶融塩腐食環境中ではき裂の分岐やき裂先端の鈍化のような特徵的な き裂進展挙動が確認され，これらはむしろき裂進展を抑制する効果がある。このようなき裂の挙動に及ほ す腐食環境効果について，主に動的な疲労き裂進展に着目して検討した。

キーワード＼cjkstart遮熱コーティング（TBC）システム， $\mathrm{Ni}$ 基超合金， $\mathrm{Y}_{2} \mathrm{O}_{3}$ 部分安定化 $\mathrm{ZrO}_{2}$, クリープ, 疲労, 高温腐食, 損傷解析 